\title{
Building a Security Council Resolution: When Numbers on Illicit Activities Matter
}

\author{
Ana PEYRÓ LLOPIS*
}

\begin{abstract}
Since the end of the Cold War, there has been an important evolution and an extensive practice of the Security Council (SC) to determine what could be considered as a threat to the peace. Currently, some situations that endanger domestic stability and rule of law are considered as constituting per se a threat to international peace and security whilst others are only taken into account as factors that undermine the stability of the region or the State. Criminal activities have often been included as indicators for the determination of instability or of a lack of rule of law. Such activities have been quantified for years and the question that arises is if the quantified impact of an illicit activity is determining to take it into consideration at a global governance level. In particular, to what extent the SC uses numerical data to consider some specific criminal activities as a factor of instability for international peace and security? The analysis of SC resolutions, in the light of reports submitted to the SC, shows that progressively, measurement has been introduced in global governance. The absence of an established practice makes it difficult to assert conclusions. However, some trends can already be identified.
\end{abstract}

Keywords: UN Security Council - Resolution - international peace and security - statistics - global governance

\section{INTRODUCTION}

According to the United Nations (UN), criminal activities, and in particular organized crime, are nowadays considered as one of the major threats to human security. One question that arises is if it is possible to use legal tools related to international peace and security to fight it. In other words, according to the UN Charter, and in particular to the Security Council (SC) practice, can some of these criminal activities be considered as a 'threat to the peace' (art. 39 UN Charter)?

Since the end of the Cold War, there has been an important evolution and an extensive practice of the SC in order to determine what could be considered as a threat to the peace. During the first years, some situations in which there were massive violations of human rights were considered as threats to the peace. Later, it was terrorism and currently situations that, in a way or another, endanger domestic stability and rule of law. Some of these situations are considered as constituting per se a threat to international peace and security whilst others are only taken into account as factors that undermine the stability of the region or the State. In the latter, it is the absence of rule of law -and not the factor of instability in itself - that is considered as a threat to the peace. In this context, criminal activities have often been included as indicators for the determination of instability or of a lack of rule of law and, consequently, as indicators to determine that a concrete situation is a threat to international peace and security.

Although any country faces illicit activities, the SC mentions such activities only in some situations as factors that challenge stability or peace. Being the SC a political body, this is not

* Senior Legal Officer, Office of Legal Affairs, United Nations. Maître de conférences, Université de Cergy-Pontoise (on leave). The present article represents solely the personal opinion of the author. Opinions expressed in this article cannot in any way be attributed to or identified with the position of the United Nations. 
surprising at all. But it is still interesting to identify when and why illicit activities are considered as factors of instability and to examine if there are trends that can be identified or even a general practice. Such illicit activities have been quantified for years, in particular by some international organizations like the United Nations Office on Drugs and Crime (UNODC) and also by Non Governmental Organizations like International Transparency as far as corruption is concerned. The question that arises as a starting point is if the quantified impact of an illicit activity is determining in order to take it into consideration at a global governance level. In particular, as the Security Council has, according to article 24 of the UN Charter, 'primary responsibility for the maintenance of international peace and security', we can ask ourselves to what extent the SC uses measurement and numerical data when dealing with illicit activities. Are measurements taken into account in order to consider some specific criminal activities as especially harmful and as a factor of instability for international peace and security?

As far as measurement is concerned, SC documents don't refer to numerical data. SC resolutions only refer to the impact or the importance that some illicit activities have especially on the economy or on rule of law in a specific country or region, and consequently, on the stability of that country or region. However, when adopting chapter 7 resolutions, the SC often refers to reports of the Secretary General (SG) or to Committees established by the SC itself, that analyse the situation critically in a specific country or region and which contain more concrete measurements.

The analysis of SC resolutions, in the light of reports submitted to the SC, shows that progressively, and in particular with the irruption of the SC concern for criminal activities, some idea of measurement has been introduced in global governance. The SC determines indeed that a situation is a threat to the peace, taking into account, amongst other things, the importance of criminal activities and refers to reports that contain more concrete measurements (I). The absence of an established practice makes it difficult to assert conclusions. However, some trends can already be identified (2).

(I) The Progressive Use of Measurement Information for the Determination of a Threat to the Peace

It is well known that chapter 7 of the UN Charter deals with action with respect to threats to the peace, breaches of the peace, and acts of aggression. In particular, article 39 states that: 'the Security Council shall determine the existence of any threat to the peace, breach of the peace, or act of aggression and shall make recommendations, or decide what measures shall be taken in accordance with Articles 4I and 42, to maintain or restore international peace and security.' The identification of what the SC considers as a threat to the peace has been a classical question, in particular since the end of the Cold War, when the SC started to really use its power of determination and included new situations as threats to the peace ${ }^{\mathrm{I}}(\mathrm{a})$. As far as criminal activities are concerned, the SC introduces in some cases a measurement of the magnitude of these activities in order to include them among the factors of instability that can lead to a threat to the peace (b).

\footnotetext{
On the evolution after the Cold War until 2003, see Wellens, 'The UN Security Council and New Threats to the Peace: Back to the Future', 8 J Conflict Security Law (2003), I5.
} 


\section{(a) New Threats to the Peace}

In the early I990s, some situations involving massive violation of human rights were considered as threats to the peace by the SC. In its Resolution 688 of 5 April I99I, on northern Iraq, the SC was 'concerned by the repression of the Iraqi civilian population in many parts of Iraq, including most recently in Kurdish-populated areas, which led to a massive flow of refugees towards and across international frontiers and to cross-border incursions which threaten international peace and security in the region'. ${ }^{2}$ A few months later, with regard to the situation in Somalia, the SC, in addition to clearly mentioning chapter 7 in its Resolution 733 (1992), justified the adoption of coercive measures in the light of 'the rapid deterioration of the situation in Somalia and the heavy loss of human life and widespread material damage resulting from the conflict in the country and aware of its consequences on stability and peace in the region'. ${ }^{3}$ This situation was determined as 'a threat to international peace and security'. ${ }^{4}$ The same year, Resolution 794 (1992) clearly determined that 'the magnitude of the buman tragedy caused by the conflict in Somalia, further exacerbated by the obstacles being created to the distribution of humanitarian assistance, constitutes a threat to international peace and security'. Two years later, on the situation in Rwanda, Resolution 955 (1994) qualified the 'genocide and other systematic, widespread and flagrant violations of international humanitarian law' ${ }^{\text {' }}$ as constituting 'a threat to international peace and security'?

After this first wave in which the SC determined that some situations of massive violations of international humanitarian law and human rights could be considered as a threat to the peace, the SC moved to a second wave of enlargement in which it determined that acts of international terrorism could also constitute a threat to the peace. For example, in its Resolution II89 (1998), adopted after the acts of international terrorism that took place on 7 August 1998 in Nairobi (Kenya) and Dar-esSalaam (Tanzania), the SC condemned such acts and considered that the suppression of acts of international terrorism is essential for the maintenance of international peace and security' ${ }^{\text {. }}$. Also in 1998, in relation with the situation in Afghanistan, the SC demanded in its Resolution I2I4 'that the Taliban stop providing sanctuary and training for international terrorists and their organizations, and that all Afghan factions cooperate with efforts to bring indicted terrorists to justice' 9 . In its Resolution 1267 (1999), clearly mentioning chapter 7 of the Charter, the SC demanded 'that the Taliban turn over Usama bin Laden without further delay' ${ }^{10}$. Following this, through Resolution 1333 (2000), determined that the failure of the Taliban authorities to respond to these demands 'constitutes a threat to international peace and security' ${ }^{\text {II }}$ and, acting again under chapter 7 , the SC reiterated its

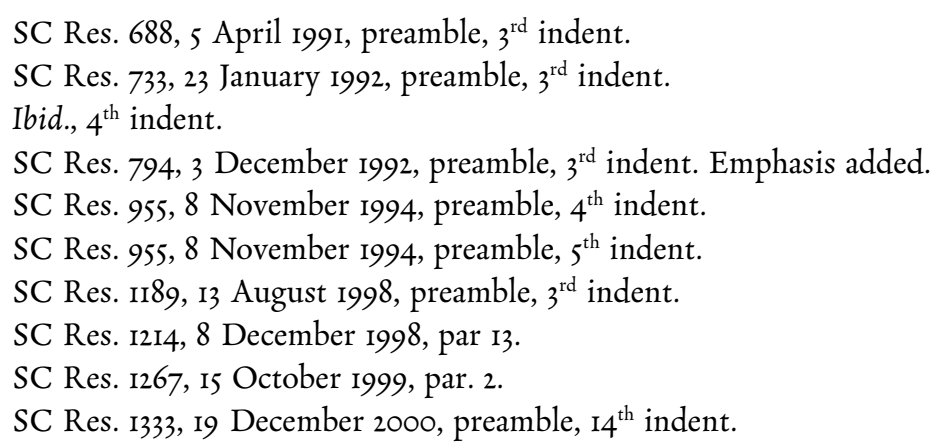


demands ${ }^{12}$. In addition, since resolution ${ }^{3} 68$ (200I), adopted after the terrorist attacks which took place on II September 200 I in New York, Washington, D.C. and Pennsylvania, the SC has directly considered 'such acts, like any act of international terrorism, as a threat to international peace and security $^{{ }^{13}}$ and acted under chapter 7 , in particular since its Resolution 1373 (200I).

While a certain approach to measurement was already implicit in the admission of massive violations of international humanitarian law and human rights as threats to the peace, as far as terrorism is concerned, the SC insists more in the nature of the threat rather than in its magnitude. Indeed, for the former, the SC refers, for example, to the 'massive flow of refugees', to the heavy loss of human life' ${ }^{\text {Is }}$ or to the 'magnitude of the human tragedy ${ }^{\text {'6 }}$. While for the latter, as the SC reminded in a recent resolution on this issue, Resolution $2 \mathrm{I} 33$ (2014), 'terrorism in all forms and manifestations constitutes one of the most serious threats to international peace and security ${ }^{17}$. Any act of terrorism, without any need of quantification is then per se a threat to international peace and security.

\section{(b) Criminal Activities as New Indicators of Instability}

In 2004, in its report A More Secure World: Our Shared Responsibility ${ }^{18}$, the High-level Panel on Threats, Challenges and Change highlighted new threats to international security. In particular, it stated that '[a]ny event or process that leads to large-scale death or lessening of life chances and undermines States as the basic unit of the international system is a threat to international security'19. Having said that, it identified 'six clusters of threats with which the world must be concerned now and in the decades ahead: Economic and social threats, including poverty, infectious diseases and environmental degradation; Inter-State conflict; Internal conflict, including civil war, genocide and other large-scale atrocities; Nuclear, radiological, chemical and biological weapons; Terrorism; Transnational organized crime ${ }^{20}$. Thus, in addition to massive human rights violations and terrorism, the Panel identified other new threats to peace and security, in particular transnational organized crime. The General Assembly has also referred to the link between peace and security and transnational organized crime and has expressed its grave concern at the negative effects of transnational organized crime, including smuggling of and trafficking in human beings, narcotic drugs and small arms and light weapons, on development, peace and security and human rights, and at the increasing vulnerability of States to such crime ${ }^{2{ }_{21}}$.

When we examine SC practice, and in particular its resolutions dealing with organized crime, however, we note that criminal activities are not considered as constituting per se a threat to the peace.

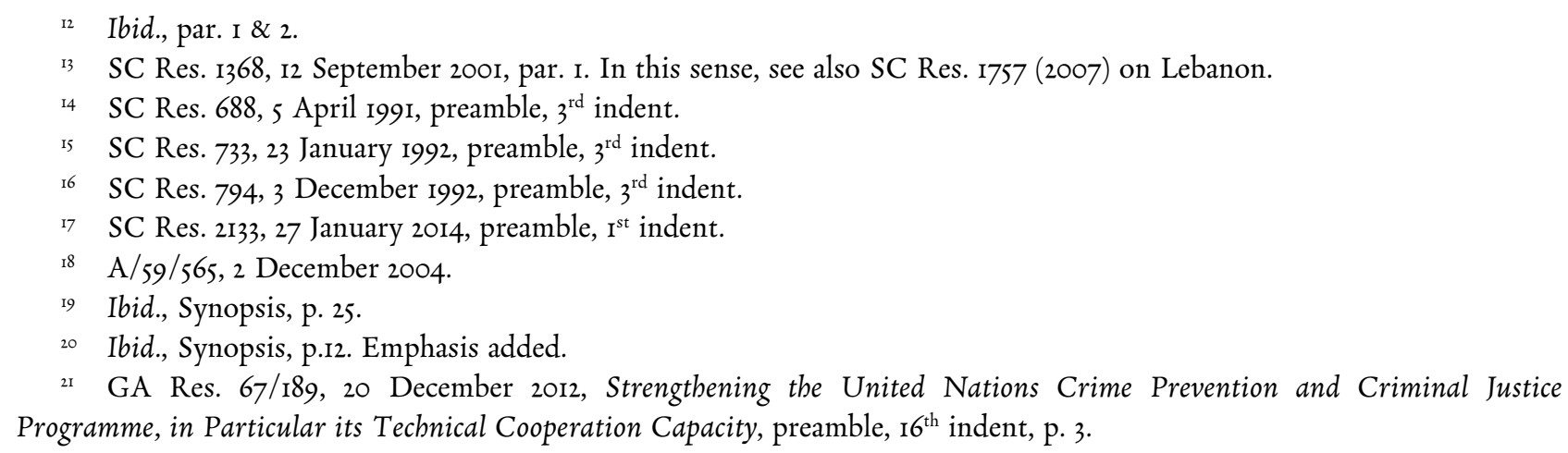


There are taken into account as factors that undermine the stability of a State or a region, and in particular the rule of law in that State. It is consequently the absence of rule of law or the situation of instability, which is considered to be a threat to the peace and not the factor that is behind such a situation. It is then a two steps process of determination in which criminal activities are treated as indicators for the determination of a threat to international peace and security. The SC has indeed progressively included a list of criminal activities as factors or indicators of instability in a country or a region for later considering that the situation in that specific country or region was a threat to the peace. Among others, we can find criminal activities such as piracy, arms trafficking, drug trafficking, natural resources trafficking in general, money laundering or corruption.

If we analyse, for example, the piracy situation off the coast of Somalia ${ }^{22}$ and in the Gulf of Guinea $^{23}$, SC resolutions have linked piracy to the general lawlessness in coastal countries and the incapacity of these states to prevent and prosecute pirates. As mentioned earlier, the situation in Somalia was primarily of concern for the international community in the light of a dramatic humanitarian situation and was then already considered a threat to the peace by the SC in its Resolution 733(1992).24 But piracy is mentioned for the first time in a SC Resolution in 2008. In its Resolution 1816 (2008), the SC determined that the incidents of piracy and armed robbery against vessels in the territorial waters of Somalia and the high seas off the coast of Somalia exacerbate the situation in Somalia which continues to constitute a threat to international peace and security in the region'. ${ }^{25}$ And acting under chapter 7, it authorized naval forces to enter Somalia territorial waters in pursuit of piracy. Resolution I816 (2008) has been renewed several times determining the existence of a threat to the peace in a similar way, which could be identified as a two steps process of determination. Firstly, piracy is considered as a factor that undermines the country, and secondly, the situation in the country is the one to be considered as a threat to the peace. Thus, the SC avoids to directly enlarge the list of threats to the peace and prefers to refer to factors that exacerbate a difficult domestic situation ('the incidents of piracy and armed robbery at sea off the coast of Somalia are an important factor exacerbating the situation in Somalia, which continues to constitute a threat to international peace and security in the region' ${ }^{26}$ ).

The SC approaches other criminal activities in a similar way, through this two steps process of determination, and includes them among the factors that undermine the stability of a specific State or region. However, in order to take them into consideration, the SC usually refers to the importance of the criminal activity at stake (i) and bases its approach on in-depth analysis undertaken on the issue (ii).

\footnotetext{
${ }_{22}$ Treves, 'Piracy, Law of the Sea, and Use of Force: Developments off the Coast of Somalia', 20 European Journal of International Law (2009), 399.

23 See among others: SC Res. 20I8, 3I October 20II and SC Res. 2039, 29 February 2012.

24 SC Res. 733, 23 January 1992, preamble, $4^{\text {th }}$ indent.

25 SC Res. 1816,2 June 2008 , preamble, $\mathrm{I}_{2}{ }^{\text {th }}$ indent.

26 SC Res. 2I25, I8 November 2013, preamble, $34^{\text {th }}$ indent. Emphasis added.
} 


\section{(i) SC General Approach to Measurement}

As far as measurement of criminal activities is concerned, the SC only refers to the magnitude of these activities in order to include them among the factors of instability that can lead to a threat to the peace. As it was underlined earlier, when the SC included human rights and international humanitarian law violations as threats to the peace, it already insisted on the fact that these violations were being massive, i.e. that an important number of violations were taking place. It then appeared that numbers could matter: if a phenomenon reaches a certain level, a certain magnitude, it may become a security issue. For example, leaving aside criminal activities for a moment and as far as public health emergencies are concerned, the SC has recently expressed its 'grave concern about the extent of the outbreak of the Ebola virus in West Africa, in particular in Liberia, Guinea and Sierra Leone'27. It had referred previously on a couple of occasions to HIV as 'one of the most formidable challenges to the development, progress and stability of societies ${ }^{28}$.

We also find this SC general approach to measurement in resolutions dealing with criminal activities. When the SC is dealing with this factor of instability, it points out for example the increase of criminal activities ('deep concern at the reported increase in drug trafficking in Guinea-Bissau since the military coup of I2 April 20I2, and at the threat it poses to stability'29 or 'increased pirate capacities' $3^{\circ}$ ) or its extended range ('gravely concerned by the extended range of the piracy threat into the western Indian Ocean and adjacent sea areas' $\left.{ }^{\prime \mathrm{I}}\right)$. An implicit reference to numerical data is also present in other statements, for example when the SC considers that piracy 'exacerbates instability by introducing large amounts of illicit cash that fuels additional crime and corruption in Somalia'. ${ }^{2}$

The question we can ask ourselves is whether this general concern for the importance, the magnitude or the scope of criminal activities relies on something more than an intuition or a perception-based measurement and/or if it is supported by specific numerical data or any other kind of measurement? As it has been alluded to previously, SC resolutions are usually adopted after reports on the situation in a specific country or region have been submitted. These reports are very often (but not only) drafted by UN Secretary General (SG) services and the SC refers to them in its resolutions. These reports are the ones that frequently include measurements and numerical data on criminal activities.

27 SC Res. 2176, I5 September 2014, preamble, $2^{\text {nd }}$ indent. Emphasis added. See also: SC Res. 2177, I8 September 2014: 'Determining that the unprecedented extent of the Ebola outbreak in Africa constitutes a threat to international peace and security', preamble, $5^{\text {th }}$ indent. Emphasis added.

${ }_{28}$ SC Res. 1983, 7 June 20II, $6^{\text {th }}$ indent. The first SC resolution on HIV was SC Res. 1308, I7 July 2000, on the Responsibility of the Security Council in the Maintenance of International Peace and Security: HIV/AIDS and International Peace-keeping Operations.

29 SC Res. 2103, 22 May 2013, preamble, ${ }^{\text {th }}$ indent. Emphasis added.

30 SC Res. 2I25, I8 November 2013, preamble, $4^{\text {th }}$ indent.

${ }_{31}$ Ibidem. Emphasis added. And of course, 'the incidents of piracy and armed robbery at sea off the coast of Somalia are an important factor exacerbating the situation in Somalia, which continues to constitute a threat to international peace and security in the region'. Ibid., preamble, last indent. Emphasis added.

32 SC Res. 2I25, I8 November 2013, par. 2. Emphasis added. 
(ii) Measurements in Reports Submitted to the SC

UN SG reports that support SC resolutions occasionally contain specific data on criminal activities. The methodology is always the same: a SC resolution that welcomes a SG report on the situation at stake and a SG report that refers to measurements made by its own services or provided by other institutions. It appears that measurements matter much more when the criminal activity at stake is corruption or piracy, or more generally speaking, when the SC identifies new factors of instability.

For example, dealing with the situation in Afghanistan, the SC had noted 'the effects of corruption on security, good governance, counter-narcotics efforts and economic development' ${ }^{33}$ and was referring to information included in 'the report of the Secretary-General of 5 March 2013 (S/2013/133) 34 . This report points out that '[o]n 7 February, the High Office of Oversight and Anti-Corruption, with the United Nations Office on Drugs and Crime (UNODC), released a survey on recent patterns and trends in relation to corruption in Afghanistan. Total bribes paid to public officials in 2012 were estimated at $\$ 3.9$ billion, an increase of 40 per cent in real terms since the previous survey in 2009. Of 6,700 Afghans surveyed (of whom 42 per cent were women), half had paid a bribe to public officials'35.

To bring another example, this time on Sierra Leone's situation, the SC firstly welcomes 'the tenth report of the Secretary-General dated 27 February 2013 (S/2013/II 8$)^{36}$. If we analyse the SG report, it contains the following data: ' $t$ ] he Sierra Leone Transnational Organized Crime Unit [...] reportedly carried out 13 law enforcement operations and investigated 52 cases, including 17 cases of illicit drug trafficking and possession, 5 cases of fraud, financial crimes and money-laundering, is cases of larceny and forgery and I case of piracy [in 2012]'37. On corruption, '[t]he Sierra Leone Anti-Corruption Commission [...] presented two cheques totalling 2.06 billion leones (about $\$ 4.2$ million), which had been recovered from corrupt individuals, to the Government's Consolidated Revenue Fund ${ }^{3}$. It also stated that there was 'a number of successful investigations and prosecutions of public employees involved in corrupt activities. On 17 December, the former Minister for Health was convicted of a number of corrupt practices, such as abuse of office and failure to comply with procurement guidelines. Four public officers were also convicted of corrupt practices and to others were indicted during the same period' 39 .

The same analysis could be undertaken in respect of South-Sudan's corruption situation for which the SG reports that ' $\mathrm{t}$ ]hrough investigations the [Anti-Corruption] Commission has also been able to retrieve misappropriated funds of the order of $\$ 60$ million, which will be returned to Government

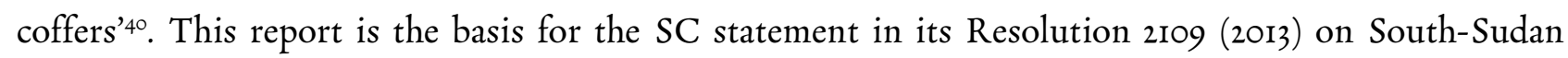
on 'the need for the Government of the Republic of South Sudan to take further steps to address

\footnotetext{
SC Res. 2096, i9 March 2013, par. 40.

Ibid., par. I.

A/67/778-S/2013/133, 5 March 2013, par. 4I.

SC Res. 2097, 26 March 20I3, preamble, $2^{\text {nd }}$ indent.

S/20I3/II8, 5 March 20I3, on the United Nations Integrated Peacebuilding Office in Sierra Leone, par. 27.

Ibid., par. 29 .

Ibidem.

S/2012/486, 26 June 20I2, par. 8.
} 


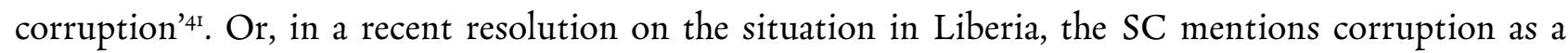
factor that undermines the country's stability: 'noting that issues related to corruption threaten to undermine stability and the effectiveness of government institutions' ${ }^{\prime 2}$. And the first SG report referred to in this resolution states that '[s]ince 2010, the Liberia Anti-Corruption Commission has submitted 24 cases for prosecution to the Ministry of Justice. ${ }^{43}$ The second SG report that is quoted in the same SC resolution also contains specific data on the Anti-corruption Commission activities to fight corruption. ${ }^{44}$

On piracy and armed robbery at sea, the SC refers again to SG reports that give concrete information on the situation. For example, in its report $S / 2012 / 783$, the $S G$ states that '[a]ccording to the United Nations Office on Drugs and Crime (UNODC), Somali pirates reportedly received about $\$ 170$ million in ransom in 2011 for hijacked vessels and crews, up from \$110 million in 20IO. The figures for 2012 are not yet available. Some of this money was channelled into the world's legal financial system. The average payment made to pirates in $201 \mathrm{I}$ was about $\$ 5$ million, although as much as \$Io million was paid for the release of a tanker.'45

More recently, the SC considered trafficking with wild fare as a factor to determine a situation as a threat to the peace in its Resolutions 2127 (2013), 2134 (2014) and 2217 (2015) (6) $^{6}$ on the Central African Republic (CAR) and in its Resolution 2136 (2014) on the Democratic Republic of Congo (DRC).47 While the $S G$ report mentioned in resolutions on $\mathrm{CAR}^{48}$ doesn't have any precise information on wildlife trafficking, Resolution 2136 (2014) on the DRC builds on a report of the Group of Experts on the DRC ${ }^{49}$ that actually has very precise information, not only on wild fare trafficking but also on the production of and trade in natural resources, in particular gold, minerals - particularly tin, tungsten and tantalum - and ivory. According to this report, all these activities would finance armed groups and criminal networks in the region. For example, as far as ivory is concerned, the report points out that ' $t$ ] he Congolese Institute for the Conservation of Nature, which oversees the national parks of the Democratic Republic of the Congo, identified 3 Io cases of elephant poaching between January 2012 and October $2013^{35}$ Another example on the situation of wild fare is given through the example

4 SC Res. 2109, II July 20I3, preamble, $4^{\text {th }}$ indent.

42 SC Res. 2II6, I8 September 20I3, on Liberia, preamble, $5^{\text {th }}$ indent.

$43 \mathrm{~S} / 2013 / \mathrm{I24}, 28$ February 2013. Twenty-fifth progress report of the Secretary-General on the United Nations Mission in Liberia, par. 56.

$44 \mathrm{~S} / 2013 / 479$, I2 August 2013, Twenty-sixth progress report of the Secretary-General on the United Nations Mission in Liberia (UNMIL): 'On 2I May, the Liberia Anti-Corruption Commission released a report on its first verification of assets belonging to public officials. Of 63 officials audited, 30 were found to have made truthful declarations, while 33 were found to have misrepresented their assets, were uncooperative or did not complete the exercise', par. 6I.

45 S/2012/783, 22 October 2012, par. 6. This report is quoted in SC Res. 2077, 21 November 2012, $6^{\text {th }}$ indent.

${ }^{46}$ It should be noted that "illicit trade, exploitation and smuggling of natural resources including gold, diamonds and wildlife poaching and trafficking" are considered, not as a threat to international peace and security but as "threaten[ing] the peace and stability of the CAR", S/RES/2217 (2015), 28 April 2015, preamble, p. 3.

47 On these resolutions, see Peters, 'Novel practice of the Security Council: Wildlife poaching and trafficking as a threat to the peace', EJIL Talk!, published on February I2, 2014, [http://www.ejiltalk.org/novel-practice-of-the-securitycouncil-wildlife-poaching-and-trafficking-as-a-threat-to-the-peace].

$48 \mathrm{~S} / 2013 / 677$, I5 November 2013 .

49 S/20I4/42, 23 January 20I4, Final report of the Group of Experts on the Democratic Republic of the Congo.

so Ibid., par. 225 . 
of the Garamba National Park, where '[i]n the 1960s, the park was home to approximately 22,000 elephants and more than 2,000 rhinoceroses. In October 2013, park authorities told the Group that a 2012 census showed fewer tan 2,000 elephants were left. They also said that they had seen one rhinoceros in 2006 but have neither seen nor found traces of any rhinoceroses since then'sr. Very precise information is also given on illicit trade of gold or minerals, stating for example that ' $[t]$ he Group estimates that 98 per cent of the gold produced in the Democratic Republic of the Congo is smuggled out of the country and that nearly all of the gold traded in Uganda - the main transit country for Congolese gold - is illegally exported from the Democratic Republic of the Congo.'52

But what happens with other criminal activities and in particular with other forms of trafficking (of drugs, arms, human beings...)? We could expect that numbers would matter too. However, SG reports do not contain numerical data but rather a general estimation of the importance of this criminal activity. In Liberia, the SC noted with concern the threats to sub-regional stability, including to Liberia, in particular posed by drug trafficking, organized crime, and illicit arms s3 in order to conclude that 'the situation in Liberia continues to constitute a threat to international peace and security in the region'.54 The SG report on the United Nations Mission in Liberia referred to in this resolution didn't contain numerical data but a general estimation of the importance of drugs trafficking: ' $r$ ] ecent seizures have indicated that the production of marijuana in Liberia exceeds domestic consumption, and cross-border networks have been established which could be utilized for trafficking and other illegal economic activities.'55

A different way of providing numerical data is to focus on very specific anti-trafficking operations. For example, on the situation in Guinea-Bissau, the report of the SG informs that '[b]etween 3 December 20I3 and 2I March 2014, the Judiciary Police and the Transnational Crime Unit conducted five joint operations, resulting in seizures totalling $6.5 \mathrm{kgs}$ of cocaine and the arrests of six nationals of Guinea-Bissau, two Senegalese and one Nigerian'56. Surprisingly, although these are the only numerical data that are handled by the SG, the SC will consequently express its deep concern at the threat drug trafficking poses to stability's7. Subsequent SC resolutions on Guinea-Bissau refer also to the link between instability and drug trafficking but SG reports do not contain any relevant numerical information on drug trafficking ${ }^{8}$. The general knowledge - the perception - of the existence of drug trafficking seems to be sufficient to take it into account as a factor of instability.

In conclusion, the way SG reports or other Committees or Groups established by the SC approach measurement of criminal activities is quite different, depending on the specific nature of the criminal

\footnotetext{
5I Ibid., par. 226.

52 Ibid., p. 3 .

53 SC Res. 1885 , I5 September 2009, preamble, Io ${ }^{\text {th }}$ indent. Emphasis added.

54 Ibid., preamble, $17^{\text {th }}$ indent.

${ }_{55} \mathrm{~S} / 2009 / 4 \mathrm{II}$, Io August 2009, Nineteenth progress report of the Secretary-General on the United Nations Mission in Liberia, par. 15 .

$56 \mathrm{~S} / 2014 / 333$, I2 May 2014, Report of the Secretary-General on developments in Guinea-Bissau and the activities of the United Nations Integrated Peacebuilding Office in Guinea-Bissau, par. 15.

57 SC Res. 2157, 29 May 2014, preamble, $10^{\text {th }}$ indent.

58 SC Res. 2103, 22 May 20I3, par. 15: 'to fight transnational organized crime and drug trafficking which threaten security and stability in Guinea-Bissau and in the subregion'.
} 
activity. However, no SC established practice can be identified yet. More so, it is difficult to identify if measurements do matter for the SC, or if reports with data matter for the SC. Maybe they are only quoted in SC Resolutions but don't have any impact at all. Being a political body, with Member States representatives, an important part of the information on situations at stake in certain regions or countries may probably come from governmental sources of SC members.

However, if we analyse more carefully the data that we find in reports submitted to the SC, it is possible to identify some trends.

\section{(2) Measurements in SC Global Governance}

The introduction of numerical data in reports that are used - or at least quoted - by the SC in order to adopt its resolutions dealing with peace and security raises the following questions. First of all, we need to identify who are the reports' data providers, in other words, who is giving measurement information to the SG or to the bodies in charge of drafting reports for the SC. Secondly, the methodology used by the data providers but also by the recipient of the reports (the SC) may provide some information. Thirdly, once we do have numerical data provided by reliable sources, we still need to consider if these data are relevant enough to be used in order to determine that a concrete criminal activity is a factor of instability that can lead to a situation of threat to the peace.

\section{(a) Reliable Data Providers?}

Reports submitted to the SC refer sometimes to other sources. These are very often United Nations sources, and in particular, as far as illicit activities are concerned, United Nations Office on Drugs and Crime (UNODC) documents. Sometimes, however, data providers are not international or domestic public authorities but private entities and, in particular, non-governmental organizations (NGOs).

For example, on piracy, SG reports refer systematically to data given by UNODC: in 20I2, '[a]ccording to the United Nations Office on Drugs and Crime (UNODC), Somali pirates reportedly received about $\$ 170$ million in ransom in 201 f for hijacked vessels and crews, up from \$IIO million in 20I0. The figures for 2012 are not yet available. Some of this money was channelled into the world's legal financial system. The average payment made to pirates in $201 \mathrm{I}$ was about $\$ 5$ million, although as much as \$IO million was paid for the release of a tanker's9; and in 2013, '[a]ccording to the United Nations Office on Drugs and Crime (UNODC), Somali pirates reportedly collected between $\$ 36$ million and \$40.5 million in ransoms in 20I2, with the average payment estimated at over \$4 million per ransom. The ransoms paid for the MT Smyrni, which was released at the beginning of 20I3, are reported to have totalled $\$$ I3 million) ${ }^{60}$.

But sometimes, data included in reports can come from other sources and, in particular, from other international organizations or from non-governmental organizations producing their own measurements and data on illicit activities. As far as other international organizations are concerned,

\footnotetext{
$59 \mathrm{~S} / 2012 / 783,22$ October 2012, par. 6. Emphasis added.

$60 \mathrm{~S} / 2013 / 623$, 2I October 2013, par. 6. Emphasis added.
} 
data provided by the World Bank are often quoted: "[a]ccording to UNODC and World Bank estimates, Somali pirates received between \$339 million and \$413 million in ransoms between April 2005 and December $2012^{\text {'61 }}$ or '[a]ccording to the World Bank report The Pirates of Somalia: Ending the Threat, Rebuilding a Nation, as at May 2012 some 3,74I seafarers of 125 nationalities had been taken hostage by Somali pirates; some of them had been in detention for as long as 1,178 days. Somalia-based piracy has resulted in an estimated yearly loss to the world economy of $\$ 18$ billion. Since 2006, annual visitor arrivals in affected East African coastal countries has dropped by almost 6.5 per cent or \%, while the tuna catch in affected areas has dropped by 26.8 per cent annually and annual fisheries exports have fallen by 23.8 per cent.' ${ }^{62}$

Information provided by Non Governmental Organizations is also sometimes taken into account. For example, on piracy, '[t]he non-governmental organization Oceans Beyond Piracy has estimated that, in 2012, \$63.5 million was spent to cover the costs of ransom delivery, vessel damage from time in captivity and the fees of negotiators, consultants and attorneys, as well as the ransoms' ${ }^{63}$. Or ' $[t]$ he overall cost of piracy to States and societies remains high. According to an assessment by the nongovernmental organization One Earth Future Foundation, the economic cost of Somali piracy in $201 \mathrm{I}$ was between $\$ 6.6$ and $\$ 6.9$ billion $^{64}$. On corruption, the Transparency International Corruption Perception Index has also been taken into account. For example, in its report on Sierra Leone, it is reminded that 'Sierra Leone ranked 123 out of the 176 countries surveyed in the Transparency International Corruption Perception Index, as opposed to 134 in $20 \mathrm{II}^{\prime 65}$.

Finally, the role of domestic data providers remains crucial. Indeed, international organizations, and in particular UNODC, rely to a large extent on information submitted by States through questionnaires. For example, UNODC receives from Member States the Annual Report Questionnaire (ARQ). However, as the Organization itself recognizes (for example each year when drafting its World Drug Report), 'challenges remain in making such estimates because of data gaps and the varying quality of the available data. One major problem is the irregularity and incompleteness in ARQ reporting by Member States. Irregular reporting may result in absence of data for some years, and may influence the reported trend in a given year. Secondly, submitted questionnaires are not always complete or comprehensive, and thirdly, much of the data collected are subject to limitations and biases. These issues affect the reliability, quality and comparability of the information received ${ }^{36}$.

The information provided comes form very different data providers, depending on the concrete situation, country or region, the SG report will include data that could be found, which doesn't necessarily mean that they are accurate and reliable.

6I Ibidem. Emphasis added.

$62 \mathrm{~S} / 2013 / 623,2 \mathrm{I}$ October 2013, par. 7. Emphasis added.

63 Ibid., par. 6. Emphasis added.

${ }_{64} \mathrm{~S} / 2012 / 783,22$ October 2012, par. 7. Emphasis added.

${ }_{65} \mathrm{~S} / 20 \mathrm{I}_{3} / \mathrm{Ir} 8$, on the United Nations Integrated Peacebuilding Office in Sierra Leone, par. 29.

66 UNODC, World Drug Report 2014, Methodology; available <http://www.unodc.org/documents/wdr20I4/Methodology_20I4.pdf>, accessed 30 November 2015. 


\section{(b) Methods of Measurement}

As far as methods of measurement are concerned, poor (or lack of) information is given in the reports submitted to the SC about the methodology used in each case.

The first method of measurement depends on information provided by domestic enforcement agencies, or by the judiciary of a country, which are usually domestic statistics. In most of the analysed reports, some information is given about cases being prosecuted, sentenced or amounts of drugs being seized, etc. However, if we have a look at the specific information provided by domestic agencies, it is difficult to assess or to measure realities from these data. For example, on corruption in Liberia, it is said in a SG report that '[s]ince 20I0, the Liberia Anti-Corruption Commission has submitted 24 cases for prosecution to the Ministry of Justice. The first conviction was handed down in November 2012, and is being appealed' ${ }^{\prime} 7$. Or on drug trafficking in Guinea-Bissau that ' $[\mathrm{b}]$ etween 3 December 20I3 and 2I March 20I4, the Judiciary Police and the Transnational Crime Unit conducted five joint operations, resulting in seizures totalling $6.5 \mathrm{kgs}$ of cocaine and the arrests of six nationals of Guinea-Bissau, two Senegalese and one Nigerian' ${ }^{68}$.

However, as it is known, these data are always partial if we search for the real scope of a concrete illegal activity. Another method of measurement allows us to have a more accurate picture of the real impact of an illegal activity: the magic of estimations, 'mythical numbers' ${ }^{69}$ are indeed used in many of the reports analysed. These estimations build on different data and, as far as the examined SG reports are concerned, they mainly refer to surveys.

Estimations and surveys are probably preferred in order to prove that an illicit activity is so important that it can be considered as a factor of instability that could even endanger peace. As pointed out earlier on corruption in Afghanistan, surveys have been released and compared. For example, UNODC made the estimation that transnational organized crime generates $\$ 870$ billion in turnover a year with the largest income coming from illicit drugs, which would account for half of its proceed $s^{70}$. These estimations build on different data and, as far as the examined reports are concerned, they sometimes refer to surveys. As the objective of reports submitted to the SC is to support SC decisions, it is important to include data that show the real scope of illicit activities, and not to reduce them to the number of cases that are being effectively investigated or prosecuted. This probably explains why the SG avoids referring systematically or exclusively to UNODC questionnaires as they essentially rely on statistics provided by member states. Reports submitted to the SC prefer to refer to estimations and surveys in order to prove that an illicit activity is so important that it could be considered as a factor of instability that could even endanger peace. For example, as mentioned earlier

\footnotetext{
${ }_{67} \mathrm{~S} / 2013 / 124,28$ February 2013. Twenty-fifth progress report of the Secretary-General on the United Nations Mission in Liberia, par. 56.

$68 \mathrm{~S} / 2014 / 333$, I2 May 2014, Report of the Secretary-General on developments in Guinea-Bissau and the activities of the United Nations Integrated Peacebuilding Office in Guinea-Bissau, par. 15.

69 Calderoni, 'Mythical numbers and the proceeds of organised crime: estimating mafia proceeds in Italy', is Global Crime (2014), 138 .

$7^{\circ}$ United Nations Office on Drugs and Crime, 20Ir. Estimating Illicit Financial Flows Resulting from Drug Trafficking and other Transnational Organized Crimes: Research report. We can find this information in a SG report which is not quoted, however, in any SC resolution: S/2012/777, 19 October 2012, Report of the Secretary-General on illicit cross-border trafficking and movement, par. 3 .
} 
on corruption in Afghanistan, the SG report informs that '[o]n 7 February, the High Office of Oversight and Anti-Corruption, with the United Nations Office on Drugs and Crime (UNODC), released a survey on recent patterns and trends in relation to corruption in Afghanistan. Total bribes paid to public officials in 2012 were estimated at $\$ 3.9$ billion, an increase of 40 per cent in real terms since the previous survey in 2009. Of 6,700 Afghans surveyed (of whom 42 per cent were women), half had paid a bribe to public officials' ${ }^{71}$. Or on trafficking of natural resources in DRC: '[t]he Group estimates that 98 per cent of the gold produced in the Democratic Republic of the Congo is smuggled out of the country. ${ }^{, 72}$ Or on piracy, "[a]ccording to UNODC and World Bank estimates, Somali pirates received between $\$ 339$ million and \$413 million in ransoms between April 2005 and December 2012'73, 'Somalia-based piracy has resulted in an estimated yearly loss to the world economy of \$18 billion'74 or '[ $t$ ] he non-governmental organization Oceans Beyond Piracy has estimated that, in 2012, $\$ 63.5$ million was spent to cover the costs of ransom delivery, vessel damage from time in captivity and the fees of negotiators, consultants and attorneys, as well as the ransoms'75.

\section{(c) Measuring the Significance of Illicit Activities}

Finally, we still need to address the initial question: are these data relevant enough to be used by the SC? We pointed out earlier that the fact that the SC is a political body, with a political agenda. It seems then that the SC will only use data if they can support its decisions. In other words, if measurements support its political agenda, they can be useful to justify some resolutions. Conversely, it doesn't work the other way: it's not because there are terrible data on a situation that the SC is going to take them into account if the situation at stake is far from its political agenda.

The objective of the determination of the significance of criminal activities is to give data to the SC to help it to determine if these criminal activities lead to a situation of instability in a country/region. This is why any measurement done and provided to the SC should include reliable and useful data on the importance that criminal activities have in the particular country/region.

Already in 2004, the High-level Panel on Threats, Challenges and Change, after having underlined that ' $\mathrm{t}$ ] ransnational organized crime facilitates many of the most serious threats to international peace and security'76, specified that '[c]orruption, illicit trade and money-laundering contribute to State weakness, impede economic growth and undermine democracy. These activities thus create a permissive environment for civil conflict.' 77 It is indeed important to find data that directly relate the importance of criminal activities with State weakness (including a threat on democratic systems) or with a difficult economic situation.

71 A/67/778-S/2013/133, 5 March 2013, par. 4r. Emphasis added.

72 S/2014/42, 23 January 2014, Final report of the Group of Experts on the Democratic Republic of the Congo, p. 3. Emphasis added.

$73 \mathrm{~S} / 2013 / 623,2 \mathrm{I}$ October 2013, par.6. Emphasis added.

$74 \mathrm{~S} / 2013 / 623,2 \mathrm{I}$ October 20I3, par. 7. Emphasis added.

75 Ibid., par. 6. Emphasis added.

${ }_{76} \mathrm{~A} / 59 / 565,2$ December 2004, p. 2I, par. 23.

$\pi \quad$ Ibid., pp. 20-21, par. 23. Emphasis added. 
If the economic impact of illicit activities matter in order to consider them as a threat to the peace, it could seem important to measure such an impact. However, reports very often avoid it for some crimes. For example, while on corruption and piracy we can easily find specific data in reports, we won't find them on drug or arms trafficking. This is not because they are more difficult to identify but probably because the latter have an evident impact on stability already known and repeated for years. For example, in 2004, the High-level Panel on Threats, Challenges and Change already stated that ' $[\mathrm{u}]$ nlike terrorists, criminals are motivated by financial gain. The single best strategy for weakening organized crime is to eliminate its ability to launder money. Transnational organized crime generates income of about $\$ 500$ billion a year, with some sources estimating triple that amount. In 2000, between $\$ 500$ billion and $\$ 1.5$ trillion were laundered. ${ }^{78}$ In 20II, the estimation made by UNODC was of an income of $\$ 870$ billion a year. And more specifically on drug trafficking, the High-level Panel on Threats, Challenges and Change also stated that it is estimated that criminal organizations gain $\$ 300$ to $\$ 500$ billion annually from narcotics trafficking, their single largest source of income. In some regions, the huge profits generated through this activity even rivals some countries' GDP, thus threatening State authority, economic development and the rule of law.'79

\section{CONCLUSIONS}

The described situation shows some trends that lead to the following conclusions:

I. The recognition of new factors of instability, like piracy or corruption, needs to be justified. As these are recent factors in SC resolutions (and probably some States were reluctant about their recognition), the SC can find it useful to have measurements to support the enlargement of its field of action. For example to justify their economic impact ('several pirate financiers are engaging in other criminal activities as well and that they have built significant paramilitary capacities on land, and thus bave the potential to destabilize the region'so) or how they undermine a society ('issues related to corruption threaten to undermine stability and the effectiveness of government institutions ${ }^{\prime 8}$ ). Data appear to be a great tool to justify decisions. Measurement becomes then a mean to enlarge the list of factors of instability that can lead to a threat to the peace.

2. Other criminal activities, like drug or arms trafficking, are considered as threats to the peace per se (like terrorism earlier), which means that no measurement is required in order to take them into account as factors of instability that undermine security. These criminal activities are important enough to be considered as factors of instability for a country or region.

3. While statistics are used to show actions already undertaken by law enforcement bodies or the judiciary to tackle a problem, estimations are used at the global governance level in order to try to show the real significance of criminal activities as factors of instability. The latter will be then especially important for global governance bodies.

\footnotetext{
$78 \quad$ Ibid., par. 174 .

79 Ibid., par. 166.

$\mathrm{S} / 2012 / 783,22$ October 20I2, par. 8. Emphasis added.

8r SC Res. 2116, I8 September 2013, on Liberia, preamble, $5^{\text {th }}$ indent.
} 